part of the shore called "The Park." It had been described to me as a petrified piece of wood from the submarine forest, which occurs along the coast; and my curiosity was raised, knowing that such wood was never petrified. I think the story was true, and certainly not improbable, because there can be little doubt that the numerous glacial erratics of that coast have travelled up the Channel from the direction of the Channel Islands. And it is quite likely that a block of silicified wood from Portland, almost as indestructible as any igneous rock among them, may have come in the same manner and from the same direction. The block was eighteen inches long and ten inches in diameter.

Hariton, Cambatdar.

O. Fisher.

\title{
LOCAL MUSEUMS.
}

Sir,-I am glad to see in your October number a letter from F. G. S. advocating the formation of local museums. Nothing could prove a greater assistance to the student in any branch of Natural History than to find in each town a series of specimens arranged so as to show the various products of the neighbourhood; but the chief difficulty which stands in the way of provincial museums is the uncertainty of their tenure. There is usually no dearth of specimens flowing in from all quarters when once a museum is set on foot, but money must also be forthcoming for cases ; rent has probably to be paid for a room to contain them, and somebody must necessarily be employed to look after the room, keep the cases dusted, and unlock the door for visitors. Under these conditions, it will, unfortunately, too often be found that local ardour becomes cooled, the sixpence or shilling from the stray visitor will very speedily be insufficient to pay for the dusting, the room is closed, and the neglected contents are either dispersed or thrown aside as useless lumber.

In a little work entitled "Hints on Local- Museums, by the Treasurer of the Wimbledon Museum Committee," ${ }^{1}$ as well as in a paper published in Chambers's Journal ${ }^{2}$ on provincial museums, F. G. S. will find some most valuable suggestions for their establishment and arrangement; but, at the same time, it is as well to bear in mind that in default of local collections, a great deal of good can be done by means of local catalogues. Let each member of a Naturalists' Club undertake whatever branch of Natural History he is best acquainted with, and compile a list of the species occurring in his own neighbourhood,- one might catalogue the fossils, giving the names of characteristic species found in each quarry ; another might devote himself to the minerals, and others would take in hand the Botanical and Zoological departments. Thus, by a well-organized division of labour, an immense amount of valuable information would be accumulated, and the result would be a record of the distribution of species throughout the country, more lasting perhaps, though less attractive, than that afforded by many a local museum.

Prtton, Barnstaple, Oetober 10, 1871.

Townshend M. HaLL.
1 R. Hardwicke, London. Price $1 s$.
${ }^{2}$ April 7, 1866. 
Prof. Owhev during a recent visit to Brighton, called on the Mayor, Mr. Alderman Webb, and left a letter for his worship, on the desirability of taking steps for forming a collection or series of the Wealden Fossils of Sussex, corresponding, as far as time and means might permit, with the illustrations of the Chalk-beds which the Local Museum owes to the liberality of Mr. Willett. Not having been fortunate to meet with the Mayor, the Professor called on Mr. Cordy Burrowes, to whose active public spirit Brighton is much indebted. The worthy Alderman, who will probably hold the office of Mayor during the meeting of the British Association, entered warmly into the views of his visitor, and pledged bimself to promote their realization to the extent of his influence.

\section{RIVER TERRACES, ETC.}

Sm,-I certainly did not understand that Colonel Greenwood was speaking solely of terraces in closed valleys. This, it appears to me, was by no means clearly brought out in his first letter. With regard to these I can only say that, owing to the general correspondence between all these terraces that I have seen and those in the open valleys, it seems more natural to refer both to the same cause, viz., the action of water in motion upon detritus that has been mainly deposited in water comparatively at rest, and this, if your summary be correct, seems to be Professor Kjerulf's opinion. Doubtless a delta may be elevated by floods, but as a rule the amount thas gained would be small compared with the mass deposited under the permanent water level. I should regard the inland terraces to be remains of deltas, either deposited in fjords during a peried of depression, or in lakes which have been first more or less filled up, then re-excavated. In order to explain this, I do not think it necessary to burst any barriers, or call in other agencies to remove them than "rain and rivers" acting upon rocks liable to erosion. In thus venturing to differ from Colonel Greenwood, I would not be thought forgetful of the great services he has rendered to geologists by his careful observation of meteoric agents and their work in nature.

St. John's College, Camaraidge.

T. G. BONNEY.

\section{ERRATA IN THE PAPER, "ON THE SYSTEMATIC POSITION OF SIVATHERIUM GIGANTEUM."}

SrR,-In my communication on this subject in the October number of this Journal, I have observed two errors, which I feel it my duty to correct, in justice to the individuals concerned. At page 440, reference is made to Dr. Canfield's " concise paper on the manner of shedding and the nature of the Prongbuck's horns." This author has given some account of these, but to Mr. A. D. Bartlett, Superintendent of the Zoological Society's Gardens, the honour of the first accurate history is due (vide P.Z.S. 1865, p. 720). ${ }^{1}$ I might

1 This substitution of Dr. Canfield's name for that of Mr. Bartlett arose from Dr. Murie having accidentally quoted the wrong year of the Proceedings $\rightarrow$ namely, 1866, in which Dr. Canfield's (not Mr. Bartlett's) paper is published.-Edir. Groc. Mag. 